\title{
DIVERSITY AND ABUNDANCE PATTERNS OF AMPHIBIANS IN REHABILITATED QUARRIES OF BAMBURI NEAR MOMBASA (KENYA)
}

\author{
Dominic Otwori ONG'OA *, Rossa Nyoike NG'ENDO **, Shadrack Muvui MUYA *, Mathew \\ Mugechi NYOIKE ****, Patrick Kenyatta MALOMZ*** and Zipporah Lagat OSIEMO * \\ * Jomo Kenyatta University of Agriculture and Technology, P. O. Box, Nairobi, Kenya, KE-62000, \\ dotwori6@gmail.com, smuya@jkuat.ac.ke, zbisieri@yahoo.com \\ ** The Catholic University of Eastern Africa, P. O. Box, Nairobi, Kenya, KE-62157-00200, \\ rossangendo@yahoo.com \\ *** National Museum of Kenya, P. O. Box, Nairobi, Kenya, KE-40658-00100, pkmalonza@yahoo.com \\ **** The Lafarge Ecosystems P. O. Box, Mombasa, Kenya, KE-81995, mmugechi@yahoo.com
}

KEYWORDS: amphibians, diversity, abundance, quarry rehabilitation, ecological gradient.

\begin{abstract}
Amphibians are sensitive to changes in the environment and are, therefore, excellent indicators of success in restoring degraded habitats. As such, a clear understanding on how amphibian populations respond to changes in the environment is required. In order for conservationists to establish if the declining trends are changing, biodiversity recovery studies are essential especially in reclaimed habitats. This study focused on the recovery of amphibians, particularly on frogs, in reclaimed quarries of the Bamburi Cement Plant near Mombasa whereby the diversity, species abundances and composition at different stages of quarry re-establishment were assessed.

The study area was divided into three zones based on the 13-year interval since the beginning of the rehabilitation process. Transect surveys and time-constrained search and size method were used for sampling 20 randomly selected sites. Sampling was done during the rainy and the dry seasons, with searches conducted between 900 and 1,600 hours during the day and between 1,800 to 2,100 hours at night. Recording of basic morphological data of collected specimens was done in the field to aid in grouping specimens before voucher materials were preserved in 10\% formalin and stored in $70 \%$ alcohol. Further identifications and confirmations matching specimens to species were carried out using specialized classification keys from the National Museum of Kenya.

Twelve species were encountered across the three zones, with Ptychadena anchietae and Phrynobatrachus acridoides, respectively, the most abundant. It was also noted that amphibian diversity across the quarries was independent of the age of ecological reestablishment $(\mathrm{r}=-0.5)$. This is indicated by the higher amphibian diversity in the south and north quarries $(\mathrm{N}=1050$ and 506 respectively) despite their relatively younger age since reestablishment compared to the central quarry $(\mathrm{N}=438)$. Lower diversity in the central quarry, although the oldest, may be largely attributed to human disturbance. Additionally, exotic plantations across the study area are poor in species since they are monocultures and, thus, not heterogeneous enough to support higher anuran diversity. Since amphibians act as one of the best measure of environmental health, rehabilitation process in the quarries need to embrace mechanisms that support maximum biodiversity recovery such as replanting of more indigenous tree species as opposed to only exotic monocultures.
\end{abstract}


RÉSUMÉ: Modèles de la diversité et de l'abondance des amphibiens dans les carrières réhabilitées de Bamburi près de Mombasa (Kenya).

Les amphibiens sont sensibles aux modifications de l'environnement et constituent donc d'excellents indicateurs du succès de la restauration des habitats dégradés.

Ainsi, une meilleure compréhension de la réponse des populations d'amphibiens aux modifications de leur environnement s'impose. Afin de permettre aux conservateurs de diagnostiquer des modifications de tendances de déclin, des études de restauration de la biodiversité sont nécessaires, surtout pour les habitats sujets à la dégradation. Cette étude s'est concentrée sur les populations d'amphibiens, en ciblant plus particulièrement les batraciens, dans les carrières réhabilitées de l'Usine de Ciment de Bamburi près de Mombasa où nous avons évalué la diversité, l'abondance et la composition spécifique lors des différentes étapes de la réhabilitation de la zone.

La région étudiée a été divisée en trois zones en fonction des étapes du processus de réhabilitation qui a commencé il y a 13 ans. L'échantillonnage a été effectué à l'aide de transectes, de méthodes de recherche et de mesure pour l'échantillonage de 20 sites choisis au hasard durant des campagnes limitées dans le temps. Le relevé des données a été effectué durant la saison sèche et la saison humide avec 900 à 1600 heures d'échantillonnage de jour et 1800 à 2100 heures d'échantillonnage la nuit. Le prélèvement des principaux paramètres morphologiques des individus collectés a été fait sur le terrain afin de faciliter le regroupement des spécimens qui ont été ensuite conservés dans du formol 10\% et mis en dépôt dans de l'alcool à $70 \%$. Par la suite, on a procédé à l'identification et la confirmation des espèces à l'aide des clés d'identification des Musées Nationaux de Kenya.

12 espèces ont été inventoriées dans les trois zones; la plus abondante étant Ptychadena anchietae suivie par Phrynobatrachus acridoides. Nous avons aussi remarqué que la diversité des amphibiens, sur le territoire étudiée, est indépendante de l'âge de la réhabilitation écologique $(\mathrm{r}=-0,5)$. Ceci est montré plus particulièrement dans le cas des diversités d'amphibiens dans les carrières sud et nord $(\mathrm{N}=1050$ et respectivement 506), malgré leur réhabilitation relativement récente, comparée à celle de la carrière centrale $(\mathrm{N}=$ 438). Dans ce dernier cas, l'impact sur la biodiversité peut être due au dérangement produit par l'activité humaine. De plus, les plantations exotiques dans la zone étudiée ont une biodiversité réduite car ce sont des monocultures manquant d'hétérogénéité pourtant nécessaire pour maintenir des diversités plus grandes d'anoures. Puisque les amphibiens sont le meilleur instrument dans l'évaluation de la santé de l'environnement, le processus de réhabilitation des carrières doit adopter des mécanismes permettant une récupération maximale de biodiversité, tel que la plantation de plus d'espèces d'arbres indigènes à l'opposé des monocultures exotiques.

REZUMAT: Modele de diversitate și abundență la amfibieni în carierele reabilitate de la Bamburi, lângă Mombasa (Kenya).

Amfibienii sunt specii sensibile la modificările mediului înconjurător, constituind astfel excelenți indicatori ai succesului restaurărilor de habitate degradate. În consecință, se impune o înțelegere mai bună a modului în care populațiile de amfibieni răspund la modificările din mediu. Pentru ca ecologii să poată stabili o eventuală modificare a tendințelor de declin în habitatele reabilitate sunt necesare studii ale refacerii biodiversității. Prezentul studiu se concentrează asupra refacerii populațiilor de amfibieni, în special anure, în carierele reabilitate ale fabricii de ciment din Bamburi, lângă Mombasa; în acest scop, în diferite stadii ale reabilitării carierei au fost evaluate diversitatea, abundența și compoziția speciilor de amfibieni. 
Zona studiată a fost împărțită în trei subzone, în funcție de modul cum a evoluat reabilitarea începută cu 13 ani în urmă. Eșantionarea s-a efectuat în 20 de locații, prin metoda transectelor și prin metoda căutării și măsurării în campanii limitate în timp, pe durata sezoanelor uscat și umed, campaniile acoperind între 900 și 1600 ore, ziua și între 1800 și 2100 ore noaptea. Înregistrarea datelor morfologice principale la specimenele colectate s-a efectuat pe teren pentru a facilita gruparea specimenelor înainte de prelevarea și conservarea eșantioanelor, care s-a făcut cu formol $10 \%$, apoi eșantioanele s-au depozitat în soluție $70 \%$ alcool. S-au efectuat, de asemenea, identificări ale specimenelor colectate la nivel de specie cu ajutorul cheilor de clasificare ale Muzeelor Naționale din Kenya.

Pe ansamblul celor 3 zone de studiu s-au identificat 12 specii, cele mai abundente fiind Ptychadena anchietae şi, respectiv, Phrynobatrachus acridoides. S-a remarcat, de asemenea, că diversitatea amfibienilor, în perimetrul carierei, nu a depins de vechimea reabilitărilor ecologice, efectuate în zonele unde aceștia au fost găsiți $(r=-0,5)$. Acest lucru este pus în evidență și de diversităţile mari ale amfibienilor din carierele sud şi nord $(\mathrm{N}=1050$ și respectiv 506), în ciuda reabilitării lor relativ recente, comparativ cu cariera central $(\mathrm{N}=438)$. Diversitatea mai mică din cariera centrală, zona reabilitată cea mai veche poate fi datorată impactului antropic. De asemenea, plantațiile exotice din zona studiată prezintă o diversitate specifică scăzută deoarece sunt monoculturi fără heterogenitatea necesară pentru a susține o diversitate mare de anure. Deoarece amfibienii sunt indicatorii cei mai buni pentru sănătatea mediului, procesul de reabilitare a carierelor necesită adoptarea de mecanisme, care să susțină o recuperare maximă a biodiversității precum replantarea mai multor specii arborescente indigene și nu doar a unor monoculturi exotice.

\section{INTRODUCTION}

Amphibians, a unique group of vertebrates containing over 6,300 known species, are threatened worldwide (IUCN, 2013). Clearly, the most important factor leading to most biodiversity losses worldwide is habitat destruction (Sala et al., 2000) and amphibians are not an exception (Amphibia Web, 2013). Surface mining, for instance, constitutes a major threat to amphibians, not only through the associated water pollution, but also through the mechanical destruction of amphibians themselves as well as their habitat. Land use typically changes following the mining process, and post-mining habitat is likely to significantly constitute lesser species diversity and maybe different species appearance (Means et al., 2004). This is likely so because changes in vegetation cover, vegetation type and composition, soil properties, and topography will therefore provide different microhabitats and resources for wildlife than those previously available before destruction (Kozlov et al., 2007).

Understanding the consequences of habitat change for biodiversity is important because the current protected area network is insufficient to safeguard the majority of the world's species (Stuart et al., 2004), and the persistence of many species depends upon the effectiveness of strategies for conserving biodiversity in human-dominated landscapes (Daily, 2001; Lindenmayer and Franklin, 2002; Semlitsch and Rothermel, 2003; Vandermeer and Perfecto, 2007). The establishment of animal communities in mine spoils is typically dependent on the setting up of the native plant communities (McKinney, 2002). This would be expected since most fauna depends on plant communities either as sources of food, nesting areas and hiding places from predators or harsh weather among others (Ireland et al., 1994; Dunger et al., 2001; DeVault et al., 2002) This has been clearly validated by birds, mammals and invertebrates (Burbridge et al., 1992). In examining such habitats, ecologists have long 
documented a small subset of native species that can exploit highly altered, anthropogenic habitats in urban and industrial settings (McKinney, 2002). However, the list of native species that have spontaneously settled in these habitats is typically small. A study by Majer et al. (1989) on colonization of mined areas in Western Australia by ants point out that regardless of mine location or substrate characteristics, the pioneers are often of the same species and are generally uncommon in the adjoining undisturbed habitats.

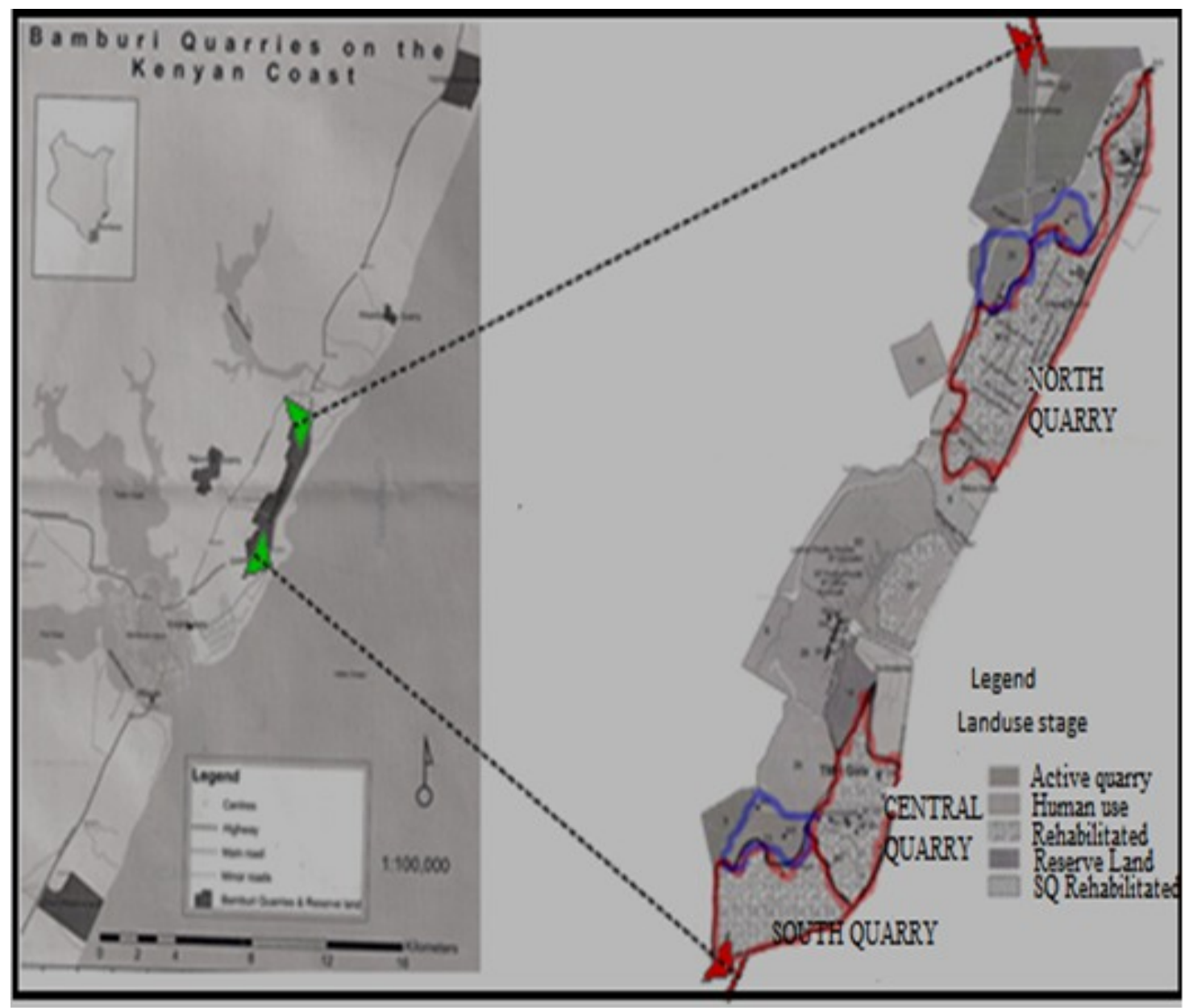

Figure 1: showing the location of the southern, central and north quarries, all at different stages of rehabilitation process.

Various studies have largely concentrated on the declining trends of amphibians (McCoy, 1994; Marsh, 2001; Collins and Storfer, 2003; Stuart et al., 2004; Gardner et al., 2007), with most barely addressing issues on the recovery of amphibian species admitting the biodiversity declines. Furthermore, biodiversity studies have mainly focused on degraded forest ecosystems, since they are presumed to have higher biodiversity (Bwong et al., 2009; Ng'endo et al., 2011; Malonza et al., 2011). In the present study, a census on amphibian populations was carried out in rehabilitated quarries that range between 12 to 42 years of age since the reclamation process. We sought to establish the diversity, abundance and composition of amphibian species in the restored habitats. 
The study was carried out in the rehabilitated mines of Bamburi Cement Plant near Mombasa, south of Kenya. This area has an altitude ranging between 0-7 $\mathrm{m}$ above the sea level, latitude of $04^{\circ} 03^{\prime} \mathrm{S}$ and longitude of $39^{\circ} 40^{\prime} \mathrm{E}$. The area experiences a warm and humid climate, with temperatures ranging between $20^{\circ} \mathrm{C}$ and $32^{\circ} \mathrm{C}$. The study area is at different gradients of recovery with central quarry, south quarry and north quarry being 42,27 and 12 years old respectively, since the beginning of the reclamation process. Rehabilitation work started with the planting of the pioneer exotic plant species, the Casuarina and Canocapus species back in 1970 s, which through gradual succession process has helped to create microclimate conditions necessary for full establishment of the present fauna and flora.

\section{MATERIALS AND METHODS}

The study site was grouped into three zones based on their age of establishment across the restored forests, grasslands and wetlands (Fig. 1). Sampled sites were randomly selected within these zones and sampling of amphibians was done using a timed species count method similar to those described by Karns (1986), Heyer et al. (1994) and Sutherland (1996). This entails quietly walking and intensively searching within all possible herpetofauna microhabitats such as under leaves, debris, decomposing tree stumps and logs, on trees, shrubs, bushes, wetlands including digging for burrowing species. Data collection was done during the wet and dry seasons and the searches were conducted between 900 to 1,600 hours in the day and between 1,800 to 2,100 hours at night. Identification of collected species was done with the help of specialized classification keys from the National Museum of Kenya. Where identification was difficult, voucher materials were preserved in $10 \%$ formalin, stored in $70 \%$ alcohol and transferred to the National Museum of Kenya for further reference and identification.

Dominance plots (Whittaker, 1965) were used to display abundance distribution patterns of species against species rank order plotted using the function radfit in package Vegan. Akaike Information Criterion (AIC) was used to select the models which included the Null, Preemption, Lognormal, Zipf and Mandelbrot, following Wilson (1991). Rényi diversities were calculated at varying scales $(0,0.25,0.5,1,2,4,8,16,32$, 64, Inf) using the function Rényi in package Vegan. This form of estimation was preferred because common diversity indices are special cases of Rényi diversity as represented in the formula:

$$
\mathrm{H} a=1 / 1-a
$$

where $a$ is a scale parameter, and Hill (1973) suggested to use the so-called "Hill numbers" defined as $\mathrm{N} a=\exp (\mathrm{H} a)$. Some Hill numbers are the number of species with $a=0$, exp $\left(\mathrm{H}^{\prime}\right)$ or the exponent of Shannon diversity with $a=1$, inverse Simpson with $a=2$ and $1=\max$ (pi) with $a=\infty$. According to the theory of diversity ordering, one community can be regarded as more diverse than another only if its Rényi diversities are all higher (Tóthmérész, 1995). In addition, diversity for the three quarries was separately calculated and also total diversity for the entire survey area using several diversity indices to test for robustness (establish if they gave more or less similar results). Species ecological distances at different sites were examined by generating a dissimilarity matrix using species abundance data. Jaccard index was used since it detects underlying ecological gradients (Faith et al., 1987). The matrix was then used to construct clusters using average linkage method which links the same two most similar sites, and at the same minimum dissimilarity. All the above analyses were calculated using package Vegan (Oksanen et al., 2010) and implemented in R (R Development Core Team, 2010). 


\section{RESULTS AND DISCUSSIONS}

Twelve species were observed $(\mathrm{N}=1994)$ from nine genera. Two frog species (Phrynobatrachus acridoides and Ptychadena anchietae) were noted as the most abundant/dominant across the three study zones. In the southern quarry, $53.8 \%$ of the collected samples were Phrynobatrachus acridoides, while 33.7\% represented Ptychadena anchietae species. A more or less similar pattern was observed in central and northern quarries Ptychadena anchietae (55.7\%), Phrynobatrachus acridoides (40.6\%); Ptychadena anchietae (55\%) and Phrynobatrachus acridoides (35.6\%) respectively. On the other hand, Bufo gutturalis and Chiromantis xerampelina were the least encountered species across the study area. Uniquely, Bufo gutturalis were only spotted in the northern quarry, Hyperolius tuberilinguis at the central quarry and Hyperolius pusillus at the southern quarry (Tab. 1). Such relatively high abundances of Ptychadena anchietae have been recorded in degraded environments, implying that this species tolerates some habitat modification (Harper et al., 2010).

Table 1: Amphibian species samples collected between October 2011 and February 2012.

\begin{tabular}{|l|c|c|c|c|}
\hline \multicolumn{1}{|c|}{ Species } & $\begin{array}{c}\text { South } \\
\text { quarry }\end{array}$ & $\begin{array}{c}\text { Central } \\
\text { quarry }\end{array}$ & $\begin{array}{c}\text { North } \\
\text { quarry }\end{array}$ & Total \\
\hline Phrynobatrachus acridoides (Cope, 1867) & 565 & 178 & 180 & 923 \\
\hline Ptychadena anchietae (Bocage, 1867) & 356 & 244 & 279 & 879 \\
\hline Ptychadena schillukorum (Werner, 1907) & 42 & 3 & 14 & 59 \\
\hline Amirana galamensis (Dumeril and Bibron, 1841) & 42 & 0 & 4 & 46 \\
\hline Kassina maculate (Dumeril, 1853) & 3 & 6 & 14 & 23 \\
\hline Chiromantis xerampelina (Peters, 1954) & 12 & 0 & 6 & 18 \\
\hline Xenopus muelleri (Peters, 1844) & 11 & 1 & 2 & 14 \\
\hline Hyperolius pusillus (Cope, 1862) & 11 & 0 & 0 & 11 \\
\hline Pyxicephalus edulis (Peters, 1854) & 2 & 1 & 4 & 7 \\
\hline Hyperolius argus (Peters, 1854) & 6 & 1 & 0 & 7 \\
\hline Hyperolius tuberilinguis (Smith, 1849) & 0 & 4 & 0 & 4 \\
\hline Bufo gutturalis (Power, 1927) & 0 & 0 & 3 & 3 \\
\hline Total & 1050 & 438 & 506 & 1994 \\
\hline
\end{tabular}

Notable variation was observed in species abundances across the sampled sites, with sites 2, 4, 6 and 19 revealing higher abundances in relation to other sites. Additionally, certain sites such as 15, 16 and 20 may have had higher alpha diversities but the abundances of their species were relatively low (Fig. 2). In most cases, higher abundances reflected uneven distribution of species within the sites, and this therefore translated to uneven distribution of species across the study zones. This implies that fluctuations in quality breeding sites, resources, or other factors were responsible for such unevenness. Changes in vegetation composition may alter habitat suitability in many ways (Runkle, 1998), particularly in determining insect communities and their distribution (Waltz and Whitman, 1997). It can, therefore, be expected that quarries with suitable breeding sites and also harboring higher diversities of plant species which may act as home for tree frogs and also for potential food sources such as insects, are likely to have high frog abundances and diversity as opposed to quarries with monoculture plantations of Casuarina and Canocapus species. 


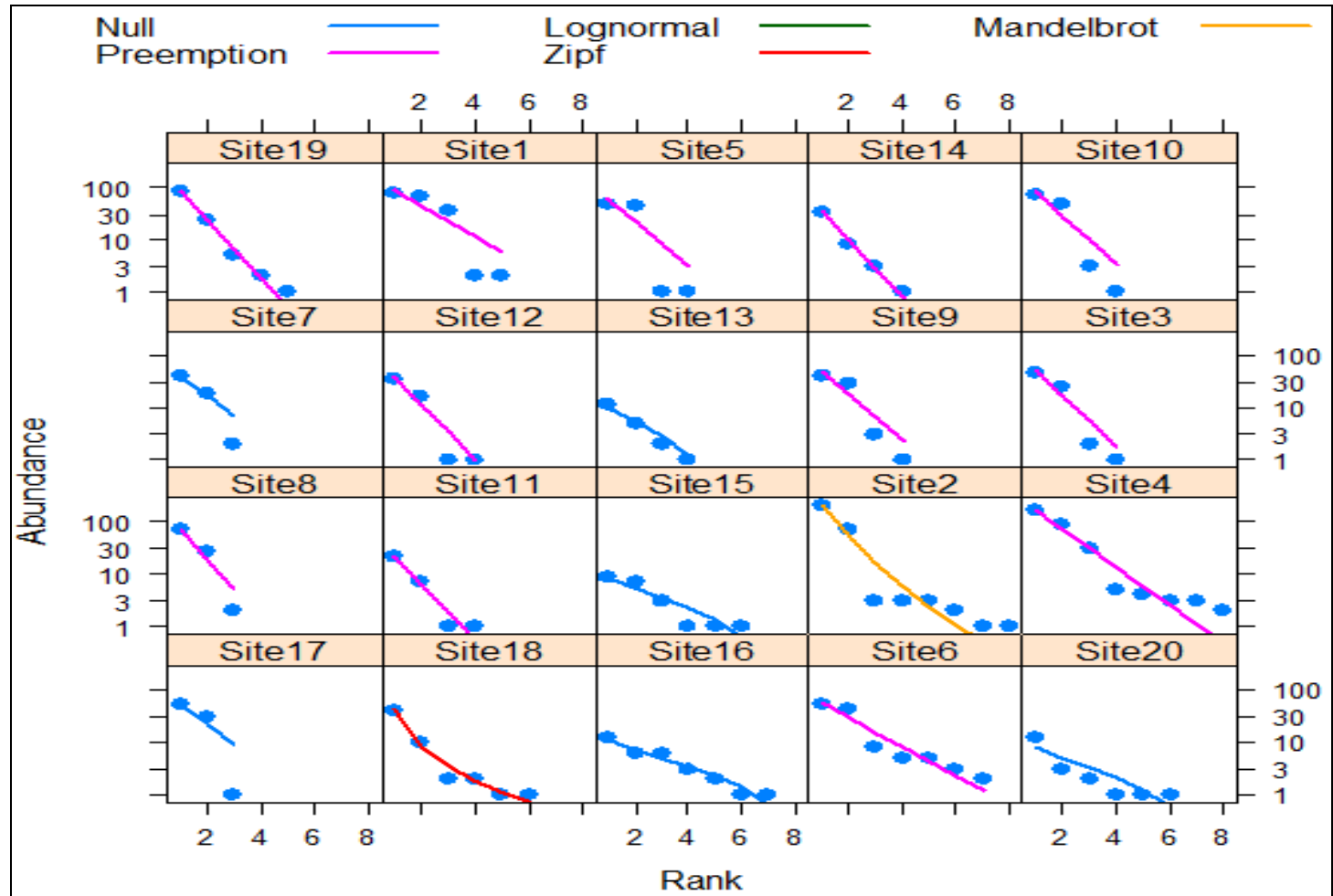

Figure 2: Rank abundance curve plots of species abundances against species rank order for 20 randomized sites using Akaike Information Criterion (AIC). Each dot on a line represents a species within sample sites. Each species is placed in descending order in relation to their abundance ranking in the quarries and as the slope of the line becomes more horizontal, it implies that the evenness level becomes stronger across the quarries. The best model has the lowest AIC, that fits the sampled data as closely as possible (best fit) and is automatically selected for the various plots accordingly.

Further, results revealed that the southern quarry had notably the highest alpha diversity ( $\alpha$-diversity) followed by the northern quarry and lastly the central quarry (i.e. ten species (37\%), nine species (33\%) and eight species (30\%) respectively). Sites 2, 4 and 6 from the southern quarry were the most diverse (i.e. $\alpha=1.33,1.33$ and 1.17 , respectively), while sites $15,16,18,19$ and 20 were the most diverse in northern quarry (i.e. $\alpha=0.750$, $0.875,0.750,0.625$ and 0.750 respectively; Fig. 3). It is important to note that the above singled sites have contributed immensely towards the species diversity, not only within their units, but generally between other units in the entire quarries. It is imperative however to appreciate the level of diversity contributions of some sites with similar number of species but different alpha diversity. For instance, sites 2 and 4 in the southern quarry have each 8 species, but their alpha indices are slightly different (i.e. 2.92 and 2.08). This observation illustrates that site 2 has many uniquely different species compared to site 4 which has many common species. Similarly the contributory diversity of sites 15 and 20 in the northern quarry differs from site 18, despite of their equal number of species (i.e. with alpha diversity measures of $1.56,1.56$ and 1.26, respectively). On the other hand, most sites from the central quarry were less diverse (e.g. sites 7, 8 and 10; Fig. 3). 


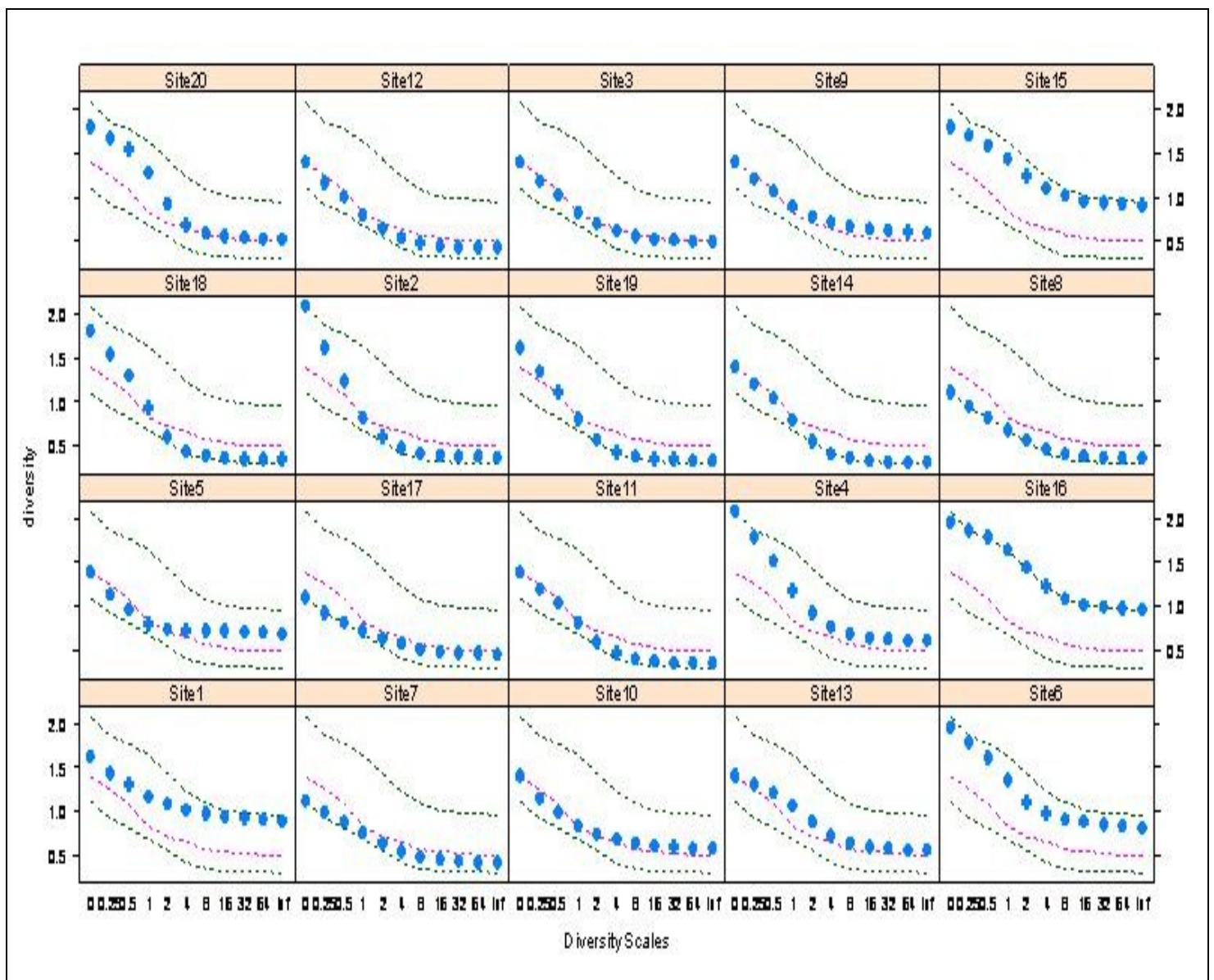

Figure 3: Rényi diversities for the 20 sampled sites within the three study sites; the dots show the values for sites, and the lines the extremes and median in the data set; a site can be regarded as more diverse if all of its Rényi diversities are higher than in another site.

These higher diversities in southern and northern quarries may be attributed to the availability of suitable breeding conditions, food and relatively stable habitats for colonization. Most ecological aspects of these places were naturally thriving without any anthropological setbacks. The ponds were bursting with life ranging from the aquatic and semi-aquatic vegetation blooms like the spirogyra, the phytoplankton and the reeds to aquatic fauna, which is important for the energy flow in the local ecosystem. Water vegetation provides attachment places for the eggs of most amphibians such as the Hyperolidae family. Besides that, phytoplankton acts as a source of food to the tadpoles in their young stage, and they also regulate nutrients, such as excess salts (bio filtration), as well as purifying water gases. Vegetation as well acts as shelter against amphibian predators. On this basis, the water vegetation occupies an important part in the rapid growth of the amphibian population in the southern quarry. This is a signal that the southern quarry is rapidly recovering its health status more than the central quarry irrespective of its age of reestablishment. 
Studies by Lehtinen et al. (2001) and Petranka et al. (2007) indicate that colonization of restored wetlands happened after many months or years. However, this concept does not fit for the central quarry, although it is the oldest since restoration process, has many artificial ponds and multispecies of indigenous vegetation in addition to the monocultures of Cassuarina and Canocapus species. Comparatively, the younger south and north quarries have higher species diversities than the central quarry. This surprisingly low $\alpha$-diversity, as well the low species richness ( $n=8$ and $n=438$ respectively) in the Central quarry are likely caused by human disturbance, since most tourism activities take place here. Forest harvesting and also the not easily biodegraded dead leaves from Cassuarina trees largely interfere with the breeding sites and also movement of ground dwelling frog species. This has direct implication on species colonization into suitable surrounding habitats as a result of reductions in dispersal potential. The quarry lacked some amphibian species, especially the tree frogs. Species such as Hyperolius pusillus, Bufo gutturalis, Chiromantis xerampelina and Amnirana galamensis were completely not spotted at this quarry. This may imply that the alterations of the vegetation structure and microhabitats inadequacy restricted their occurrence in this area (Urbina-Cardona et al., 2006). Furthermore, the wetlands available in the form of ponds interconnected by channels are as well getting extinct due to suffocations by the mangrove ferns, which are characteristically invasive species. This has made the water volume and flow to reduce drastically. Even though shallow water points with a surface mat of vegetation are considered ecologically valuable especially to the life and breeding of amphibians, for the case of the mangrove ferns it is unlikely true because the ferns propagate siltation, which might ultimately dispel water from the grounds, thus, affecting the habitat quality. These findings confirm a study at the Brazilian Atlantic rain forest by Becker et al. (2007), which showed that amphibian species that hang on aquatic habitats may be threatened if the ground conditions are not carefully assessed during rehabilitation process. On overall, there were no significant differences across the quarries $(\mathrm{P}>0.05)$.

Species composition characteristics in the three studied quarries provided a dual revelation that perhaps predicts and explains the ecological position of the amphibian species at the rehabilitated quarries. The results from the clustering show that the pairing of sites was largely independent of the age of quarry re-establishment. However, there were sites from the same quarry that showed similarities in species composition. For example, sites 13 and 20 and sites 2 and 4 among others. Most sites, however, seem to have a relatively large ecological distance though occurring in the same quarry, where as for some the ecological distance is small. For instance, sites 8 and 11 in the central quarry have a large ecological distance and, thus, most species occurring in these sites are different. On the contrary, the sites 7 and 12 in the same quarry have a small ecological distance and, therefore, imply that their species composition is more or less similar (Fig. 4). There is no continuity in the dispersion of particular amphibian species within any given quarry and this may be suggesting that the habitat heterogeneity in the underlying ecological influence the composition of species at different quarries.

Most species are stringent habitat specialists and it appears that slight habitat encroachment or modification will affect their population size. The Chiromantis xerampelina species, for instance, was seen to prefer emergent hydrophytes, such as the water lilies and water hyacinth on shallow waters for breeding purposes. Similar preference was also observed in Hyperolius tuberilinguis, which had preference for water-reeds. Destruction of such reeds could, therefore, mean an interruption on their life cycle and, consequently, population 
declines. A similar behaviour was witnessed in the African Bull frog (Pyxicephalus edulis), which was found to survive in created or restored wetlands with long hydro-periods (more permanent water bodies). Freda et al. (1991) observed that Bull frogs' embryonic and larvae stages were highly sensitive to high acidic levels within their habitats. Although quantification of acidic levels of the quarry wetlands was not done, this would be a reason for the absence of Bull frogs in the central quarry (Monello et al., 1999; Henning et al., 2006; Fuller et al., 2011).

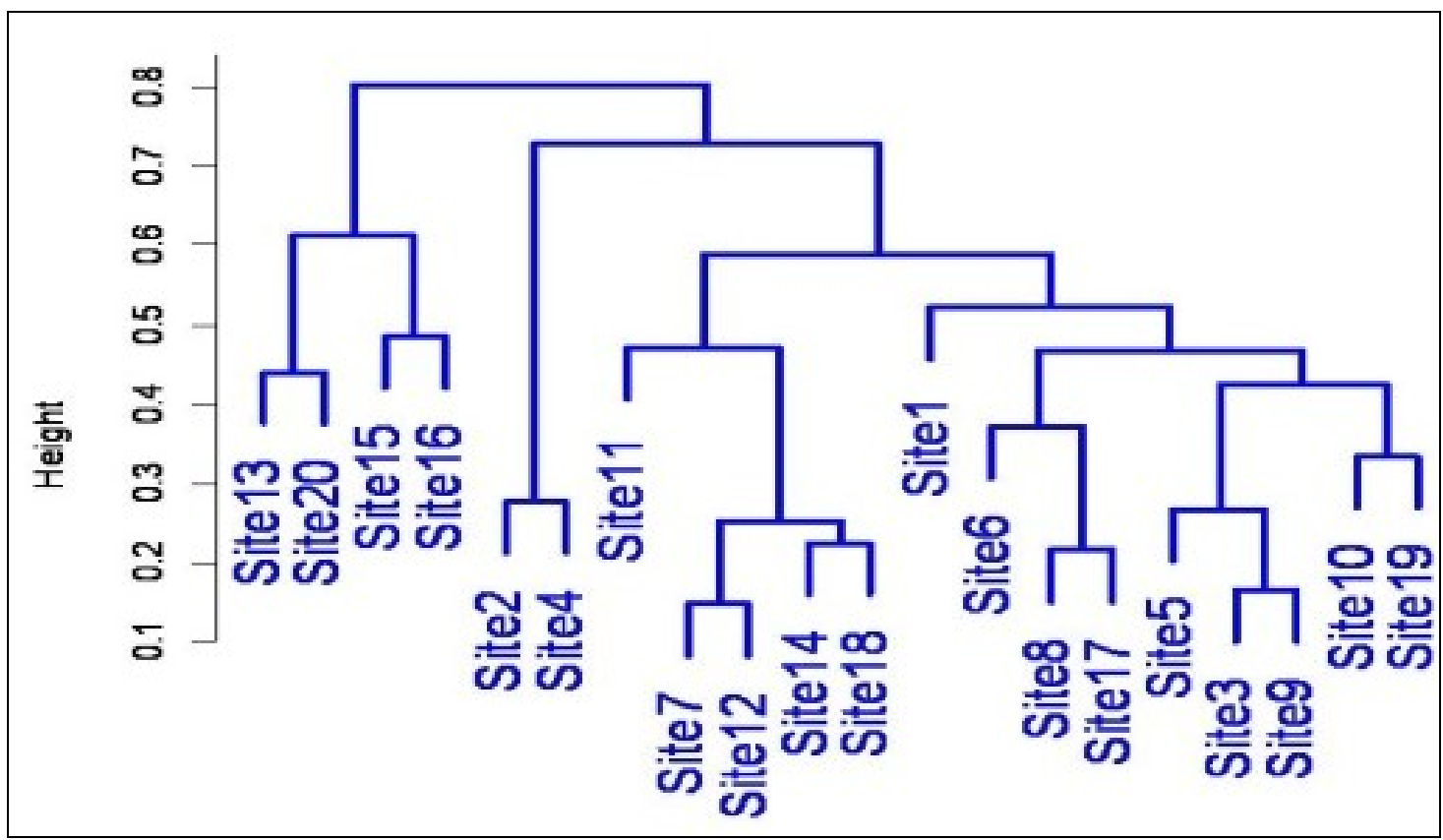

Figure 4: Cluster dendrogram for all 20 sites (using Jaccard index) showing analysis of ecological distance to examine species composition for the entire area of study area; each cluster starts by combining the two most similar sites to each other and then proceeds by combining groups to groups; fusion of sites/groups was done using average linkage method.

\section{CONCLUSIONS}

The species diversity patterns and composition in the reclaimed mining quarries provide interesting information that helps to infer into the ecological conditions currently prevailing at the region and also the conservation measures that can be taken to improve the habitat quality for higher species diversity.

The noted species patterns are perhaps due to unfavourable conditions for the tenancy of amphibians that ranges from breeding, shelter, hydrological cycle, food web complexity, dispersal corridors in the neighbourhood and the edge effect.

The results indicate that the observed amphibian species list does not exhaust the known pool of amphibian species of the coastal region of Kenya, which is of about 30 (Malonza et al., 2006; Malonza et al., 2011).

In order to maximize on biodiversity recovery as a whole in the rehabilitated quarries, the restoration process should embrace the use of indigenous plant species, as well as to improve the habitat quality such as the artificial and natural breeding areas. These aspects perhaps would be the cradle of the missing amphibian species. 


\section{REFERENCES}

1. AmphibiaWeb., 2013 - Information on amphibian biology and conservation, Web application, 2013, http://amphibiaweb.org, accessed Jul 17, 2013.

2. Becker C. G., Fonseca C. R., Haddad C. F. B., Batista R. F. and Prado P. I., 2007 - Habitat split and the global decline of amphibians, Science, 318, 1775-1777.

3. Burbridge A. H., Leicester K., MacDavitt S. and Majer J. D., 1992 - Ants as indicators of disturbance at Yanchep National Park, Western Australia, Journal of the Royal Society of Western Australia, 75, 89-95.

4. Bwong B. A., Chira R., Schick S., Veith M. and Lötters S., 2009 - Diversity of Ridged Frogs (Ptychadena) in the easternmost remnant of the Guineo-Congolian rain forest: morphology, bioacoustics, molecular markers, Salamandra, 45, 129-146.

5. Collins J. P. and Storfer A., 2003 - Global amphibian declines: sorting the hypotheses. Diversity and Distributions, 9: 89-98.

6. Daily G. C., 2001 - Ecological forecast, Nature, 411, 245.

7. De Vault T. L., Scott P. E, Bajema R. A. and Lima S. L., 2002 - Breeding birds of reclaimed coal-mine grasslands in American Midwest, Journal of Field Ornithology, 73, 268-275.

8. Dunger W., Wanner M., Hauser H., Hohberg K., Schulz H. J., Schwalbe T., Seifert B., Vogel J., Voigtlander K., Zimdars B. and Zulka K. P., 2001 - Development of soil fauna at mine sites during 46 years after afforestation, Pedobiologia, 45, 243-271.

9. Faith D. P., Minchin P. R. and Belbin L., 1987 - Compositional dissimilarity as a robust measure of ecological distance, Vegetation, 69, 57-68.

10. Freda J., Sadinski W. J. and Dunson W. A., 1991- Monitoring of amphibian populations with respect to the effects of acidic deposition, Water, Air and Soil pollution, 55, 445-462.

11. Fuller T. E., Pope K. L., Ashton D. T. and Welsh H. H. Jr., 2011 - Linking the distribution of invasive amphibians to habitat conditions in a managed river system in Northern Carolina, Restoration Ecology, 19, 204-213.

12. Gardner T. A., Barlow J. and Peres C. A., 2007 - Paradox, presumption and pitfalls in conservation biology: The importance of habitat change for amphibians and reptiles, Biological Conservation, 138, 166-179.

13. Harper E. B., Measey G. J., Patrick D. A., Menegon M. and Vonesh J. R., 2010 - Field guide to the amphibians of the Eastern Arc Mountains and Coastal Forests of Tanzania and Kenya, Nairobi Camerapix Publishers International.

14. Henning J. A. and Shirato G., 2006 - Amphibian use of Cheralis River flood plain Wetlands, North Western Naturalist, 87, 209-214.

15. Heyer W. R., Donnelly M. A, Diarmid M. R. W., Hayek L.-A. C and Foster M. S. (eds), $1994-$ Measuring and Monitoring Biological Diversity: Standard Methods for Amphibians. Smithsonian Institution Press, Washington D. C., 364.

16. Hill M. O., 1973 - Diversity and evenness: a unifying notation, Ecology, 54, 427-473.

17. International Union for the Conservation of Nature - IUCN, 2013 - IUCN Red list of threatened species, Version 2013.1, http://www.iucnredlist.org, accessed Jul 17, 2013.

18. Ireland T. T., Wolters G. L. and Schemnitz S. D., 1994 - Recolonization of wildlife on a coal strip-mine in Northwestern New-Mexico, Southwestern Naturalist, 39, 53-57.

19. Karns D. R., 1986 - Field Herpetology: Methods for the study of Amphibians and Reptiles in Minnesota, James Ford Bell Museum of Natural History, University of Minnesota, Occasional Paper, 18 September.

20. Kozlov M. V. and Zvereva E. L., 2007 - Industrial barrens: extreme habitats created by nonferrous metallurgy, Reviews in Environmental Science and Biotechnology, 6, 231-259.

21. Lehtinen R. M. and Galatowitsch S. M., 2001 - Colonization of restored wetlands by amphibians in Minnesota, American Midlands Naturalists, 145, 388-396.

22. Lindenmayer D. B. and Franklin J. F., 2002 - Conserving Forest Biodiversity: A Comprehensive Multiscaled Approach, Conservation Biology, 11, 1053-1068. 
23. Majer J. D., 1989 - Long-term colonization of fauna in reclaimed land, in: Animal in primary succession - the role of fauna in reclaimed lands, Majer J. D., (ed.), Cambridge University press, Cambridge, 143-174.

24. Malonza P. K., Wasonga V. D., Muchai V., Rotich D., Bwong B. A. and Bauer A., 2006 Diversity and biogeography of herpetofauna of the Tana River Primate National Reserve, Kenya, Journal of East African Natural History, 95, 95-109.

25. Malonza P. K., Bwong B. A. and Muchai V., 2011 - Kitobo Forest of Kenya, a unique hotspot of herpetofaunal Diversity, Acta Herpetologica, 6, 149-160.

26. Marsh D. M., 2001 - Fluctuations in amphibian populations: a meta-analysis, Biological Conservation, 101, 327-335.

27. Marsh D. M. and Trenham P. C., 2001 - Metapopulation dynamics and amphibian conservation, Conservation Biology, 15, 40-49.

28. McCoy E. D., 1994 - "Amphibian decline": a scientific dilemma in more ways than one, Herpetologia, 50, 98-103.

29. McKinney M. L., 2002 - Urbanization, biodiversity, conservation, Bioscience, 52: 883-890.

30. Means D. B., Dodd C. K Jr., Johnson S. A. and Palis J. G., 2004 - Amphibians and fire in longleaf pine ecosystems, Conservation Biology, 18, 1149-1153.

31. Measuring and Monitoring Biological Diversity: Standard Methods for Amphibians, Smithsonian Institution Press, Washington D. C., 364.

32. Monello R. J. and Wright R. G., 1999 - Amphibian habitat preferences among artificial ponds in the Palouse region of Northern Idaho, Journal of herpetology, 33, 298-303.

33. Ng'endo R., Kairu E., Osiemo Z. and Ogol C., 2011 - Morphological variation of Ridged Frogs of the Taita Hills, Kenya, Acta Herpetologica, 6, 275-288.

34. Oksanen J., Blanchet F. G., Kindt R., Legendre P., O’Hara R. B., Simpson G. L., Solymos P., Henry M., Stevens H. and Wagner H., 2010 - Community Ecology Package Version, 1, 17-2.

35. Petranka J. W., Harp E. M., Holbrook C. T. and Hamel J. A., 2007 - Long-term persistence of amphibian populations in restored wetland complex, Biological conservation, 138, 371-380.

36. R Development Core Team., 2010 - R: a language and environment for statistical computing, R Foundation for Statistical Computing, Vienna, Austria, (http://www.Rproject.org).

37. Sala O. E., Chapin F. S., Armesto J. J., Berlow R., Bloomfield J., Dirzo R., Huber-Sanwald E., Huenneke L. F., Jackson R. B., Kinzig A., Leemans R., Lodge D., Mooney H. A., Oesterheld M., Poff N. L., Sykes M. T., Walker B. H., Walker M. and Wall D. H., 2000 - Global biodiversity scenarios for the year 2100, Science, 287, 1770-1774.

38. Semlitisch R. D. and Rothermel B. B., 2003 - A foundation of conservation and management of amphibians, 242-259, in R. D. Semlitisch, (ed.), Amphibian Conservation, Smithsonian Books, Washington D. C.

39. Stuart S., Chanson J. S., Cox N. A., Young B. E., Rodrigues A. S. L., Fishman D. L. and Waller R. W. 2004 - Status and trends of amphibian declines and extinctions worldwide, Science, 306, 1783-1786.

40. Sutherland W. J., 1996 - Ecological Census Techniques, Cambridge University Press.

41. Tóthmérész B., 1995 - Comparison of different methods for diversity ordering, Journal of Vegetation Science, 6, 283-290.

42. Urbina-Cardona J. N., Olivares-Peres M. and Reynoso V. H., 2006 - Herpetofauna diversity and micro environment correlates across a pasture edge interior ecotone in tropical rain forest in Los Tuxtlas Biosphere Reserve of Veracruz, Mexico, Biological conservation, 132, 61-75.

43. Vandermeer J. and Perfecto I., 2007 - The agricultural matrix and a future paradigm for conservation, Conservation Biology, 21, 274-277.

44. Waltz A. M. and Whitman T. G., 1997 - Plant development affects arthropod communities: opposing impacts of species removal, Ecology, 78, 2133-2144.

45. Whittaker R. H., 1965 - Dominance and diversity in plant communities, Science, 147, 250-260.

46. Wilson J. B., 1991 - Methods for fitting dominance/diversity curves, Journal of Vegetation Science, 2, 35-46. 